\title{
Profile of Male Students' Physical Fitness in Riau
}

\author{
Indra Tri Handoko*, Jonni, Syahrastani \\ Faculty of Sport Science \\ Universitas Negeri Padang \\ Padang, Indonesia \\ indratrihandoko.ith@gmail.com
}

\begin{abstract}
The research aimed to get information about the male students' physical fitness level in SMA Negeri 1 Bungaraya Siak Regency of Riau. It is descriptive research that involved 40 male students, aged 16-19. Data collecting tool is in the form of a series of tests of physical fitness for ages 1619 years consisting of (1) the 60-meter dash, (2) cable car lift body, (3) baring sit 60 seconds, (4) vertical jump and (5) 1200meter run for the son. Data analysis with descriptive statistics. The research results revealed 40 students son IPA SMA Negeri 1 Bungaraya Siak Regency of Riau indicates that the level of physical fitness on the classification of "very well" frequency = $0(0.0 \%)$, "good" frequency $=3(7.5 \%)$, "medium" frequency $=15(37.5 \%)$, "lack" frequency $=22(55 \%)$, and "less" $=0$ $(0.0 \%)$. to value $($ mean $)=13.33$, with a total value of $=533$. Based on the results of the research of the physical fitness level of the male students is on the category of less.
\end{abstract}

\section{Keyword-physical fitness, male, students}

\section{INTRODUCTION}

Physical fitness is the body's ability to do activities without meaningful consideration and still have energy reserves to do other activities. Physical fitness classification according to the world health organization is defined as being healthy and fit, healthy being free both physically and mentally from all illnesses, while being fit is a person's ability to carry out daily activities and also health assistance tailored to what is available.

Physical fitness not only reflects health, but also how to measure individuals who carry out daily activities. There are three important things in physical fitness, namely: Physical, organ function, muscle response. Physical associated with muscles, bone and fat parts, organ functions related to the heart system, blood vessels and lungs, while the muscle response is related to speed, flexibility, strength, endurance [1].

"physical fitness is an ability to carry out normal daily activities vigorously and fully prepared, without experiencing significant exhaustion and still having energy reserves to enjoy leisure activities and emergency events that come suddenly " [6].

Based on the above quote, it means that physical fitness is a picture of the ability of functions and systems in every physical activity. Physical fitness is really needed by every student to gain agility, ability and high learning ability, one to maintain or improve physical fitness by doing regular exercise and daily physical activities that are beneficial for health in school.

Students who have good physical fitness are marked by not getting tired easily, always actively moving, have good cardiovascular endurance while students who do not have fitness are characterized by frequent drowsiness when studying, fatigue easily when exercising, and muscle aches after exercising, of course things this is very influential on learning physical education in schools.

The level of physical fitness of students will be able to be measured through elements of physical conditions including running 60 meters fast, lifting the body (pull up) for 60 seconds the man, Baring sit (sit up) for 60 seconds, jump upright ( vertical jump), run or 1200 men's meters[3]. This criterion is intended for measuring test items. Criteria for measuring physical fitness. If implemented properly, sports teachers can improve the physical fitness of high school students [3].

Physical fitness can not be separated from various nutritional intake factors obtained, because with a good nutritional intake it will be very supportive to improve physical fitness. Nutrient intake needed by the body as a source of energy in carrying out activities, as well as a result of the body, and the builder of body cells. So, for the sake of physical fitness, the consumption of balanced and sufficient energy and vitamins, minerals, and so on.

Besides other factors that affect a person's physical fitness level are physical activity, age, genetic (heredity), nutritional intake, nutritional status. Physical education activities provided by teachers in schools and the accuracy of teachers in choosing learning methods that can be chosen, specific material in the training of various movement and sports skills in Physical Education learning.

The Bungaraya State 1 Senior High School is one of the schools located in the Bungaraya sub-district of Siak Regency, moving to areas far from residential areas, and about $30 \mathrm{~km}$ from the city center, the journey to get to Bungaraya 1 High School takes about 20 minutes.

Judging from the school layout, in The Bungaraya State 1 Senior High School it has a large area and land. Seen further from the environment and physical activities undertaken by students of The Bungaraya State 1 Senior 
High School who are in the countryside, managing the layout of schools in the countryside and access to school which is much higher for students who use the school, both private vehicles and transported by transportation. With access to schools far from residential areas and quiet roads and protection of distance from home to school makes students lazy to walk to school related to physical activities, students prefer to use vehicles, easy, efficient and faster access to get the goal.

Less physical activity or student movement is also influenced by technological advancements that improve this technology making it easy in all fields to make each activity cheaper, lighter, and more comfortable.

From observations made by the writer directly at the State Senior High School 1 Bungaraya Siak Regency, that is the author sees the low level of physical education of students. This can be seen at the time of physical education learning, many students are less enthusiastic, get tired quickly, are not focused, lethargic. When the level of physical fitness can affect student learning activities, the learning objectives are not very useful.

Based on the description in the background of the problem and the theory of the experts, the writer wants to conduct research that refers to the "Physical Fitness Profile of the Male Science Students of the State Senior High School 1 Bungaraya"

\section{RESEARCH METHODS}

This type of research used in this research is descriptive research. Then the data collected will be analyzed using descriptive statistical analysis techniques, namely by describing the data and presenting the data in the form of frequency distributions [10]. The population of this research is 40 male students of class X, XI and XII, consisting of 40 men [10]. Sampling taken in this study using the Total Sampling technique[10]. Total Sampling is a sampling technique where the number of samples is equal to the population of 40 people. [9]. Data collection techniques in this study were Indonesian Physical Fitness Test for High School students aged 16-19 years to determine the level of physical fitness of students with the 60 meter Rapid Running test instrument, body lift test for men, Baring sitting for 60 seconds , Jump upright, Run 1200 meters [3].

The data that has been collected will be analyzed using descriptive statistical analysis techniques, with the following formula[9].:

$$
\begin{array}{ll}
P= & \frac{f}{n} x 100 \\
\mathrm{P}= & \text { Number of Percentage of Answers } \\
\mathrm{f}= & \text { Frequency } \\
\mathrm{n}= & \text { Number of respondents }
\end{array}
$$

\section{RESEARCH RESULTS AND DISCUSSION.}

\section{A. Data Description}

The results of the study presented in this chapter concern the description of the physical fitness level of male science students at SMAN 1 Bungaraya, Siak Regency, Riau Province, which were sampled as the data of this study. In this study only examined data on the physical fitness level of Natural Sciences students in class X, XI, and XII at Bungaraya N 1 Senior High School, Siak Regency, Riau Province. Before determining the level of physical fitness of students, first the data is collected and entered into the list of physical fitness test scores.

This physical fitness test uses different units, the test questions are in the form of time (seconds), meters and counts. Data that uses 60 meters of running time and 1200 meters of distance running, data that uses meters of jumping up and down uses the body lifting / pulling / and lying / sitting calculation [7]. After obtaining the physical test results of physical examination for male students of State Senior High School 1 Bungaraya Siak Regency, Riau Province, then the data is processed according to TKJI norms [7]., and the physical examination of male students of State Senior High School 1 Bungaraya in Siak Regency is in accordance with the existing categories of the Indonesian Physical Fitness Test norms[7].

\section{B. Data Analysis}

In this study, the data taken is the physical fitness level of male students of class X, XI, and XII State Senior High School 1 Bungaraya, Siak Regency, Riau Province, and is directly taken through an Indonesian physical test, so that the description of the data can be easily seen and seen. The data is made in tabular form which can be seen as follows :

Table 1. of Frequency Distribution of Indonesian Physical Freshness Tests for Male Students of State Senior High School 1 Bungaraya, Siak Regency.

\begin{tabular}{|c|c|c|c|}
\hline $\begin{array}{l}\text { Amount } \\
\text { Volues }\end{array}$ & Frequency & $\begin{array}{l}\text { Percentage } \\
(\%)\end{array}$ & $\begin{array}{l}\text { Classifita } \\
\text { tion }\end{array}$ \\
\hline $22-25$ & 0 & $0 \%$ & $\begin{array}{c}\text { Very } \\
\text { Well }\end{array}$ \\
\hline $18-21$ & 3 & $7.5 \%$ & Well \\
\hline $14-17$ & 15 & $37.5 \%$ & Is on \\
\hline $10-13$ & 22 & $55 \%$ & Less \\
\hline $5-9$ & 0 & $0 \%$ & $\begin{array}{c}\text { Very } \\
\text { Less }\end{array}$ \\
\hline Jumlah & 40 & $100 \%$ & \\
\hline
\end{tabular}

Based on the frequency table above, then out of 40 students as many as 3 students $(7.5 \%)$ have Indonesian Physical Fitness Test results with a range of grades 18-21 good classification, then as as many as 15 students (37.5\%) have Indonesian Physical Fitness Test results with a range of grades 14-17 are classified as medium, after that as many as 22 students $(55 \%)$ have the results of the Indonesian Physical Fitness Test with a range of grades 10-13 less classification. For more details can be seen in the graph below: 


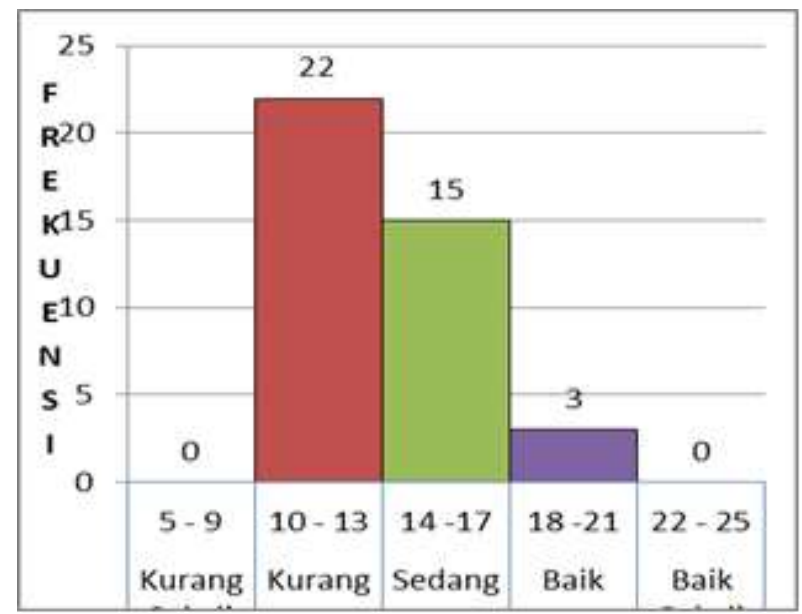

Table 2. Bar chart of the Physical Fitness Level of Male Students of Natural High School 1 Bungaraya.

\section{Research Result}

Descriptive analysis of percentage using assessment table and norm norm classification table of Indonesian Physical Fitness Test for children aged 16-19 years [2,7]., which were sampled were male students of Natural Sciences class X, XI and XII in State Senior High School 1 Bungaraya Siak Regency, Riau Province .

The research findings show and 40 male high school students in class X, XI and XII male high school students in State Senior High School 1 Bungaraya Siak Regency, Riau Province, no one has a very good level of physical fitness classification, as many as 3 students $(7.5 \%)$ have the results of the Indonesian Physical Freshness Test with a range of grades 18-21 good classification, then as many as 15 students $(37.5 \%)$ have the results of the Indonesian Physical Freshness Test with a range of grades 14-17 moderate classification, after that as many as 22 students $(55 \%)$ has the results of the Indonesian Physical Fitness Test with a range of values from 10-13 to less classification. For more details can be seen in the explanation below:

Percentage data identify that the physical fitness level of male students of Natural Sciences in class X, XI and XI of State Senior High School 1 Bungaraya Siak Regency, Riau Province is in the poor classification, based on the table of physical fitness frequency distribution of male students of State Senior High School 1 Bungaraya Siak Regency Riau Province, the average for the value $($ mean $)=13.33$, with the total value $=533$, so the level of physical fitness of male students of State Senior High School 1 Bungaraya Siak Regency, Riau Province is in the poor category.

\section{Discussion}

Based on the research findings described above, physical fitness is an aspect of physical ability that supports student success in carrying out various activities in daily life without causing significant fatigue. So is the case with male students of Natural Sciences High School, especially at the State Senior High School 1 Bungaraya Siak Regency, Riau Province, they should have a good level of physical fitness in order to carry out daily tasks properly and efficiently without feeling tired in the body and still have spare power both to cope with emergencies and to enjoy time spent with active recreation.

Basically a person's physical fitness is influenced by physical activity and exercise that is carried out daily. The better physical activity a person does, the better the level of physical fitness. From the results of the descriptive analysis of research data it is known that from 40 male respondents in the State Senior High School 1 Bungaraya Siak Regency, Riau Province shows that the physical fitness of students according to the norms of Indonesian Physical Fitness Level is in the classification of "very good" or not $0 \%$, "good" as many as 3 people or $7.5 \%$, "moderate" classification as many as 15 people or $37.5 \%$, "poor" classification as many as 22 people or $55 \%$, and classification of nonexistent or $0.0 \%$.

Guided by the results of the physical fitness profile of the State Senior High School 1 Bungaraya students in Siak Regency, Riau Province above, it can be said that the overall level of physical fitness of students is classified as Poor. the factor that affects a person's maximum oxygen volume is one measure of one's physical fitness level, namely activity, heredity, age [1]. Maximum oxygen volume is one indicator to express a person's level of physical fitness. Where is the better level of physical fitness. The factors that influence a person's level of physical fitness are as follows (1) age, (2) genetic (heredity), (3) physical activity. factors that affect physical fitness, including: "(1) regulating food, (2) resting regularly, and (3) exercising regularly"[5].

Referring to the findings of the study which state that the physical fitness level of male students of Natural Sciences is generally in the less classification, it can be concluded that the components of physical fitness which include muscle strength, cardiovascular endurance, muscle endurance, flexibility, agility, coordination, balance and accuracy can not be developed properly by students, especially students of State Senior High School 1 Bungaraya Siak Regency, Riau Province in their daily physical activities. So that students do not have good body fitness, because the role of physical fitness does not play out as evidenced by the level of physical fitness of students in general research findings are in the less classification.

\section{CONCLUSIONS AND SUGGESTIONS}

Based on the results of the analysis and discussion described in the previous section, it can be concluded that the level of physical fitness of male students of the Natural Sciences of State Senior High School 1 Bungaraya, class X, $\mathrm{XI}$, and XII, which is in the classification is very good, none, only 3 people who have good classification, 15 people have medium classification and 22 people have less classification. The level of physical fitness of male students of Natural Sciences State Senior High School 1 Bungaraya Siak Regency of Riau Province which is in a very good classification does not exist, obtained a total value $=533$, and the average value of physical fitness level $=13.33$, based on the frequency distribution table physical fitness of male students of Seklah Middle Senior High School 1 Bungaraya Siak Regency of Riau Province, the average for the physical fitness value of male students of Natural 
Sciences in Senior High School State 1 Bungaraya Siak Regency is categorized as Less.

Based on the results of the research and conclusions above, the authors can provide suggestions including, To the physical education and sports physical education teachers at the State Senior High School 1 Bungaraya Siak Regency, Riau Province to pay more attention to the development of students by increasing physical fitness, so students can receive the teaching given well. Head of physical education and sports physical education teachers in the State Senior High School 1 Bungaraya Siak Regency, Riau Province, directing students to take part in extracurricular activities at school, so that students become more active and developing. To students to pay more attention to nutrition and healthy lifestyles, such as applying adequate rest periods, regular exercise and avoiding bad habits such as sleeping late and smoking, and increasing motivation in physical education. To the principal, in order to support the activities of Physical Education subjects, and to complete sports facilities and infrastructure to increase student motivation in physical activities. To the community and parents, in order to provide guidance and supervision of students' bad habits and in using information technology and pay attention to the consumption of nutritious food and healthy lifestyle of students daily.

\section{REFERENCES}

[1] A. Agus. "Olahraga Kebugaran Jasmani Sebagai Suatu Pengantar”. Padang: Suka Bina Press. 2012, pp. 45.

[2] Gusril. "Perkembangan Motorik pada masa Anakanak". Dirjen Olahraga Departemen Pendidikan Nasional. 2004, pp. 56.

[3] Arsil. "Evaluasi Pendidikan Jasmani dan Olahraga". Padang: Wineka Media. 2015, pp. 30-32.

[4] Sugiono. "Cara Mudah Menyusun Skripsi, Tesis, dan Disertasi”. Yogyakarta. 2013, pp. 47.

[5] Sudjana. "Metode Statistika Edisi ke-6". Bandung: Tarsito. 2005, pp. 86.

[6] Ismaryati. “Tes Pengukuran Olahraga”. Surakarta: Sebelas Maret University pres. 2008, pp. 98.

[7] Bafirman. "Pembentukan Kondisi Fisik". Padang: Wineka Media. 2008, pp. 35. 